Tropical Journal of Pharmaceutical Research June 2012; 11 (3): 413-419

(C) Pharmacotherapy Group, Faculty of Pharmacy, University of Benin

Benin City, 300001 Nigeria.

All rights reserved.

Available online at http://www.tjpr.org

Research Article

http://dx.doi.org/10.4314/tjpr.v11i3.10

\title{
Anticancer Activity of Limonia acidissima Linn (Rutaceae) Fruit Extracts on Human Breast Cancer Cell Lines
}

Debasish Pradhan $^{1 *}$, GitanjaliTripathy ${ }^{1}$ and Santosh Patanaik ${ }^{2}$

${ }^{1}$ University Department of Pharmaceutical Sciences, Utkal University, Orissa751004, ${ }^{2}$ All India Institute of Medical Sciences, New Delhi-01, India

\begin{abstract}
Purpose: To evaluate the anti-cancer activity of Limonia acidissima Linn (Rutaceae) which has long been used traditionally for various infectious and malignant diseases.

Methods: The fruit extract of Limonia acidissima Linn was obtained by macerating 3 times with methanol and then concentrating it at reduced pressure. Bioassay of the extract was carried out to assess the anticancer activity. Breast cancer cell lines, SKBR3 and MDA MB435, were used for in-vitro cell proliferation, cell viability assay, and cell cycle analysis of the extract.

Results: Bioassay of the extract of Limonia acidissima Linn. showed that a fraction (fraction 3) of the ethanol extract had anticancer activity against SKBR3 and MDA-MB435 human breast cancer cells. The effective dose $\left(E D_{50}\right)$ of Limonia acidissima Linn. fraction 3 was 56.1 and $30.6 \mu \mathrm{g} / \mathrm{ml}$ for SKBR3 and MDA-MB435, respectively. After $48 \mathrm{~h}$ of exposure, this fraction $(100 \mu \mathrm{g} / \mathrm{ml})$ significantly reduced cell proliferation in both cancer cell lines. In MDA-MB435 cells, cell cycle analysis showed that fraction 3 induced the accumulation of cells in G2/M phase, but no significant change in cell cycle was detected in SKBR3 cells.

Conclusion: The results indicate that the extract fraction could induce cell cycle arrest. However, further investigation is needed to assess the molecular mechanisms of the anticancer activities of this plant.
\end{abstract}

Keywords: Anticancer antivity, Breast cancer cell lines, Limonia acidissima Linn. , G2/M arrest 


\section{INTRODUCTION}

Breast cancer is one of the most prevalent malignancies in women worldwide. In India, breast cancer is the second to cervical cancer in frequency, with an estimated incidence rate of 17.2 per 100,000 , and has increased in all parts of the country during the past decade [1]. Although breast cancer therapy is usually multimodal, cytotoxic drugs still play important roles in increasing survival rate and quality of life [2]. Therefore, the development and search for novel and effective anticancer agents have become very important [3].

To date, many cytotoxic agents including natural products isolated from plant sources have been investigated for discovery of potential novel anticancer drugs [4]. Higher plants have long been shown to be good and reliable sources for the development of novel anticancer drugs. In India, many plants have been used in the traditional treatment of various malignancies over the centuries.

Limonia acidissima Linn, syn. Feronia limonia (Rutaceae) is a moderate-sized deciduous tree grown throughout India. The fruits are woody, rough and used as a substitute for bael in diarrheoa and dysentery $[6,7]$. The bark and leaves of the plant are used for vitiated conditions of vata and pita while the fruits are used for treating tumours, asthma, wounds, cardiac debility and hepatitis. The fruit contains flavonoids, glycosides, saponins and tannins [5]. Some coumarins [4,5] and tyramine derivatives [6] have also been isolated from the fruits of limonia. The leaves are reported to possess hepatoprotective activity [8] while the fruit shells contain antifungal compounds, namely, psoralene, xanthotoxin, 2, 6-dimethoxybenzoquinone and osthenol [9].

However, the anticancer property of this plant has not yet been investigated. Therefore, this prompted us to investigate the inhibitory effect of the fruit extract of this plant on the growth of two different breast cancer cell lines, SKBR3 and MDA-MB435.

\section{EXPERIMENTAL}

\section{Plant material and extraction procedures}

Ripe fruits of Limonia acidissima Linn. were collected from the forest of Bhubaneswar hill situated in the eastern part of India in the month of May and identified by Dr SK Sahu, a taxonomist at Utkal University, Vanivihar, Orissa, India. A voucher specimen (no. 161) was deposited in the herbarium of the Department of Botany, Utkal University. The fruits were cut into small pieces and the pulp was separated. The pulp was shade-dried, milled and the powder $(1.5 \mathrm{~kg})$ macerated three times (for 7 days each) with $15 \mathrm{~L}$ of 95 $\%$ ethanol at room temperature [6]. The extracts were concentrated under reduced pressure, at $60{ }^{\circ} \mathrm{C}$ resulting in a combined yield of $80.5 \mathrm{~g}$.

The extract $(35 \mathrm{~g})$ was dissolved in distilled water $(100 \mathrm{ml})$ and $15 \mathrm{ml}$ of the solution column chromatographed, dry packed using a glass column (inner diameter $4 \mathrm{~cm}$, length $60 \mathrm{~cm})$, equilibrated with water $(100 \mathrm{ml})$ and sonicated for $15 \mathrm{~min}$ in an ultrasonic bath. The detailed flow process is illustrated in Fig 1. The suspension was centrifuged at 20,000 rpm (approx. 42,000 g) for $30 \mathrm{~min}$ and then applied onto the Diaion ${ }^{\circledR} \mathrm{HP}-20$ column; the eluent was collected to get the water soluble fraction (fraction 1). The precipitate was dissolved in methanol-water (1:1, $100 \mathrm{ml})$ and $90 \%$ methanol $(150 \mathrm{ml})$ to obtain fractions 2 and 3, respectively. Each supernatant was repeatedly treated as described above. The precipitate was dissolved in ethyl acetate to obtain fraction 4. The chemical composition of each fraction was monitored on TLC using silica gel $\mathrm{GF}_{254}$ Alufolien (Merck) and developed with chloroform/ethanol (90:10, v/v). Phytosteryl glucoside was used as reference. After developing them, the TLC was sprayed with anisaldehyde-sulfuric acid and heated in an oven at $100{ }^{\circ} \mathrm{C}$ for $1-2 \mathrm{~min}$. 


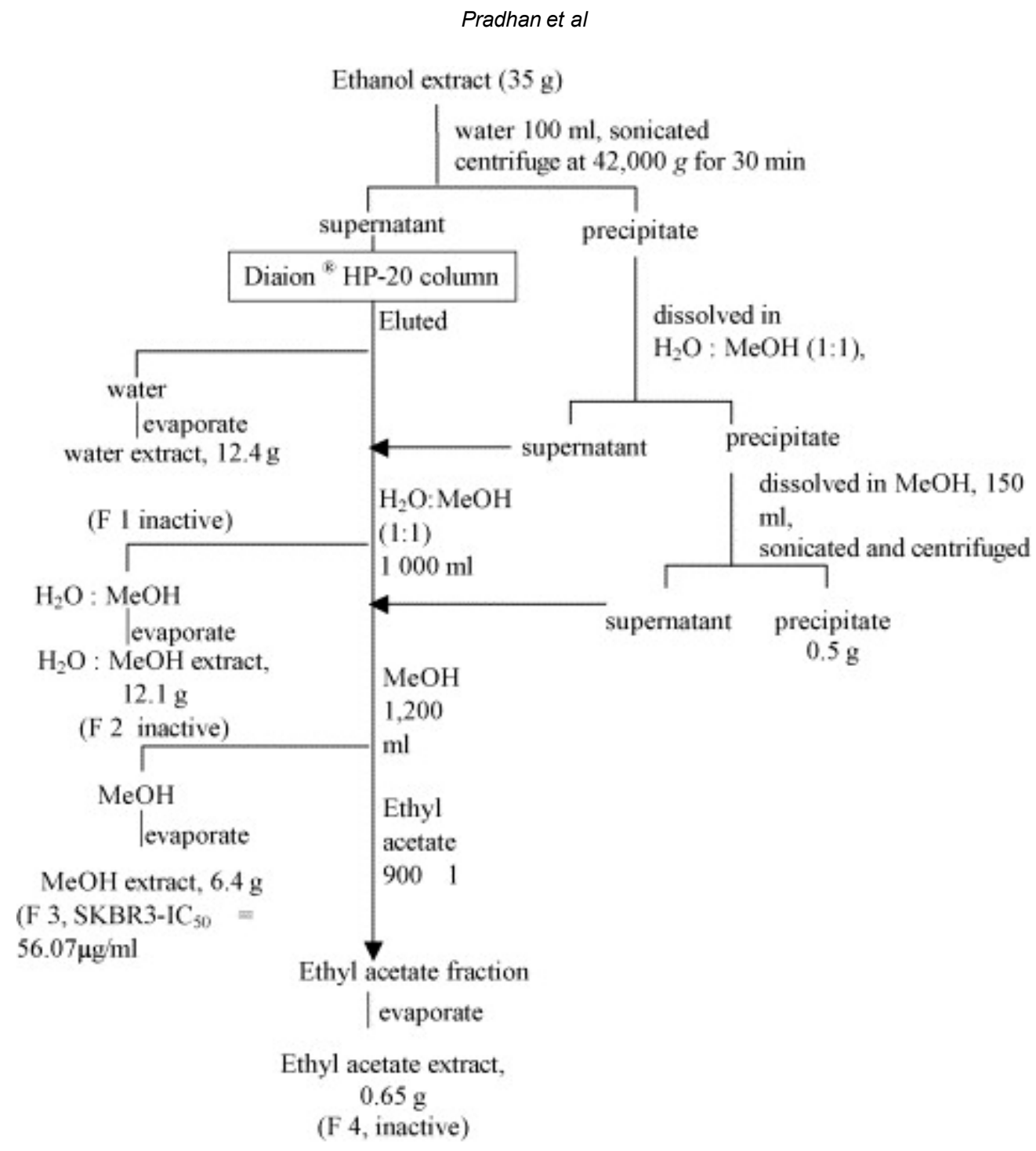

Fig 1: Bioactivity-guided fractionation of Limonia acidissima fruit extract by column chromatography.

\section{Preparation of extracts for anticancer experiments}

The fruit extracts were dissolved in dimethyl sulfoxide (DMSO, Sigma, St. Louis, USA) except for the water fraction (fraction 1) which was dissolved in water. For all experiments, the final concentrations of the tested compounds were prepared by diluting the stock with the culture medium.

\section{Cell lines and culture}

The breast cancer cell lines, SKBR-3 (ATCC No. HTB-30) and MDA-MB435 (ATCC No. HTB-129), were procured from New Scientific Agencies, Bangalore, India. SKBR-3 is human breast cancer cell line with overexpression of HER2/neu receptor and devoid of ER receptor while MDA-MB435 breast cancer cell line was devoid of both ER receptor and HER2/neu expression [7]. The 
cells were cultured in DMEM (Promo Cell, Germany) supplemented with $10 \%$ heatinactivated foetal bovine serum (Promo Cell, Germany) and $1 \%$ penicillin-streptomycin (Promo Cell, Germany). The cells were incubated at $37{ }^{\circ} \mathrm{C}$ in a humidified atmosphere with $5 \% \mathrm{CO}_{2}$.

\section{Cell proliferation assay}

Cell proliferation assay was carried out by seeding a total of $1 \times 10^{4}$ cells per well in a 96-well plate. After $36 \mathrm{~h}$ of incubation, various concentrations of fruit extracts were added to the wells to obtain final concentrations of 1 , 10,100 and $500 \mu \mathrm{g} / \mathrm{ml}$, respectively. Control groups were mixed with DMSO to obtain a final concentration of $1 \%$. Doxorubicin was used as positive control. The cells were incubated for an additional $48 \mathrm{~h}, 50 \mu \mathrm{l}$ of MTT [3-(4,5-dimethylthiazol-2-yl)-2,5-diphenyl

tetrazolium bromide] (1 $\mathrm{mg} / \mathrm{ml}$, Sigma) in phosphate buffered saline (PBS) was added to each well, and incubated for $4 \mathrm{~h}$ at $37^{\circ} \mathrm{C}$. The medium was removed and formazan was dissolved in DMSO and the optical density measured at $590 \mathrm{~mm}$ using a bioassay reader (Biorad, USA) [9].

\section{Cell viability assay}

The cells were suspended in a 96-well plate at the same concentration as was used for the cell proliferation assay and then incubated for $24 \mathrm{~h}$ at $37^{\circ} \mathrm{C}$ with $5 \% \mathrm{CO}_{2}$. Various concentrations of the fruit extract, as indicated above, were added to each well, with DMSO as control. After $48 \mathrm{~h}$ of incubation, the cells were trypsinized and viable cell counting was performed by enumerating cells which excluded trypan blue dye using a haemocytometer.

\section{Cell cycle analysis}

To determine cell cycle, $1 \times 10^{6}$ cells were suspended in each tissue culture dish and treated with the fruit extract at final concentrations of 80 and $160 \mu \mathrm{g} / \mathrm{ml}$ for SKBR3. For MDA-MB435, cells were treated with the fruit extract at final concentrations of 60 and $120 \mu \mathrm{g} / \mathrm{ml}$. DMSO (1\%) was added to the control group. After treatment with fruit extract for $48 \mathrm{~h}$, the cells were collected and incubated with reagents as described in the protocol of Cycle Test ${ }^{\mathrm{TM}}$ Plus DNA reagent kit (Becton Dickinson Immunocytometry System). The DNA content of the cells was measured by flow cytometry [10]. All samples were analysed within $3 \mathrm{~h}$ by FACS Carlibur using Cell Quest software.

\section{Statistical analysis}

The experiments were performed in triplicate. The data for cell proliferation and viability assays are expressed as mean \pm standard deviation. $\mathrm{ED}_{50}$ values were calculated by regression analysis. A $p$ value $<0.05$ was considered significant.

\section{RESULTS}

The ethanol fraction revealed eight bands. Three bands were yellow-orange with $R_{f}$ values of $0.12,0.25$ and 0.30 . Five bands were violet-blue with $R_{f}$ values of $0.17,0.38$, $0.41,0.56$ and 0.61 . The violet-blue reference compound appeared at the $R_{f}$ value of 0.17 .

Growth inhibition by the fruit extract on human breast cancer cells is shown in Fig 2 . At $48 \mathrm{~h}$, the $E D_{50}$ values of fraction 3 were $56.1 \pm 3.8$ and $30.6 \pm 1.5 \mu \mathrm{g} / \mathrm{ml}$ for SKBR3 and MDA-MB435, respectively. Since fraction 3 was found to have an inhibitory growth effect on these cell lines, this fraction was used to further investigate the effect of the fruit extract on these cells.

\section{Effect of extract on cell viability}

The results indicate that at a concentration of $100 \mu \mathrm{g} / \mathrm{ml}$, both cell lines showed low viability of $<50 \%$ compared to that of the control group. No cell inhibition was observed at $10 \mu \mathrm{g} / \mathrm{ml}$. 


\section{Cell cycle induced by extract}

SKBR3 treated with fraction 3 at a final concentration of $160 \mu \mathrm{g} / \mathrm{ml}$, shown in Fig 3, indicate a slight $S$ phase block by decreasing the population of S phase from 12.9 to $7.2 \%$. For MDA-MB435 cell cycle progression, the result showed that the treated MDA-MB435 cells (at a concentration of $120 \mu \mathrm{g} / \mathrm{ml}$ ) increased the population of $\mathrm{G} 2 / \mathrm{M}$ phase from 24.4 to $45.7 \%$ compared with that of the control group (Fig 4).

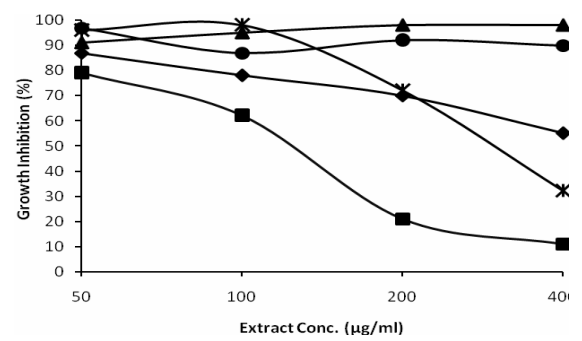

2(A)

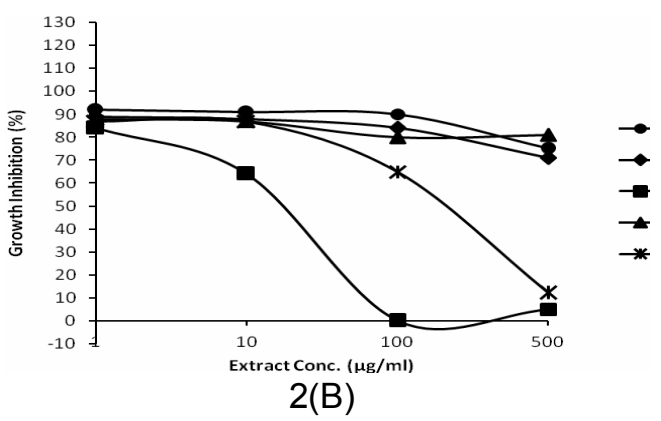

Fig 2: Inhibitory effect of Limonia acidissima extract on SKBR3 (A) and MDA-MB435 (B) breast cancer cell lines.

\section{DISCUSSION}

The ethanol extract of the plant fruit was fractionated in column chromatography, according to the compound polarity. The eluting solvents were transferred to the column, starting from water, water-methanol (1:1), methanol and ethyl acetate. They were subjected to MTT test for antiproliferative activities. The water soluble fraction comprised the most polar compounds, i.e., inorganic salts, sugars, amino acids, saponins; the water-methanol soluble fraction contains the glycosides while the ethyl acetate fraction is composed of aglycones. The methanol extract showed cytotoxicity against the SKBR3 and MDAMB435 breast cancer cell lines. This inhibitory growth activity of the treated cells acted in a dose-dependent manner which was also confirmed by the cell viability with the trypan blue exclusion assay. This observation suggests that some active components of this extract are in the methanol fraction.

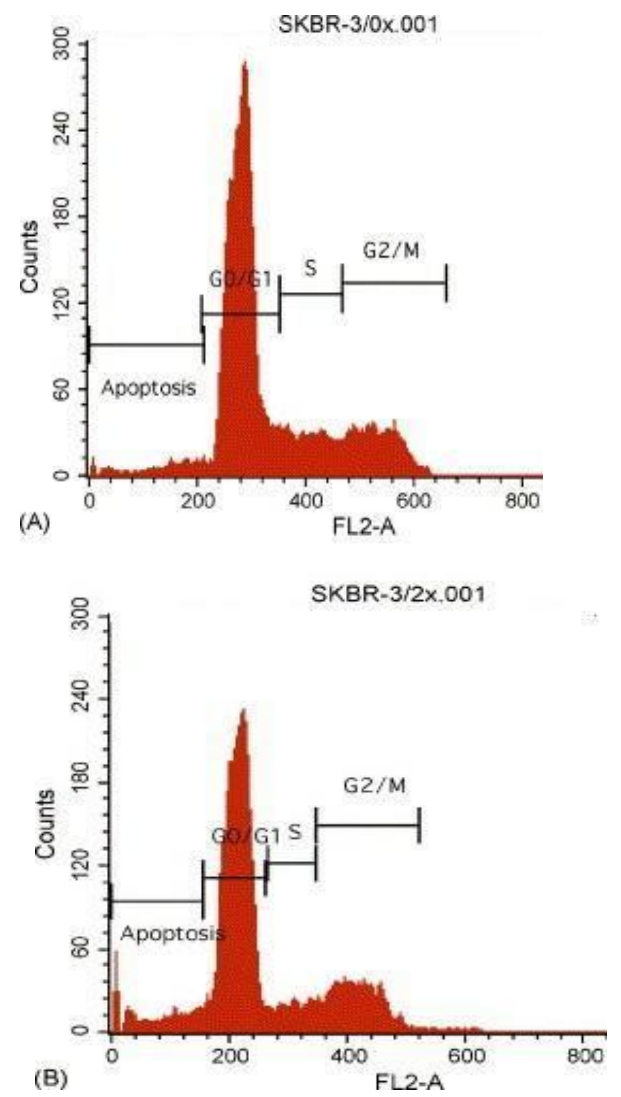

Fig 3: Inhibition of cell cycle progression in breast cancer cell lines analysed by flow cytometry: (A) Cell cycle analysis of SKBR3 cells without plant extract at $48 \mathrm{~h}$. GO/G1 $=69.4 \%, \mathrm{~S}=12.9 \%$, $\mathrm{G} 2 / \mathrm{M}=15.1 \%$; (B) Cell cycle analysis of SKBR3 cells after treatment with plant extract fraction 3 for $48 \mathrm{~h}$ at $160 \mu \mathrm{g} / \mathrm{ml}: \mathrm{GO} / \mathrm{G} 1=66.2 \%, \mathrm{~S}=7.2 \%$, $\mathrm{G} 2 / \mathrm{M}=19.6 \%$ 

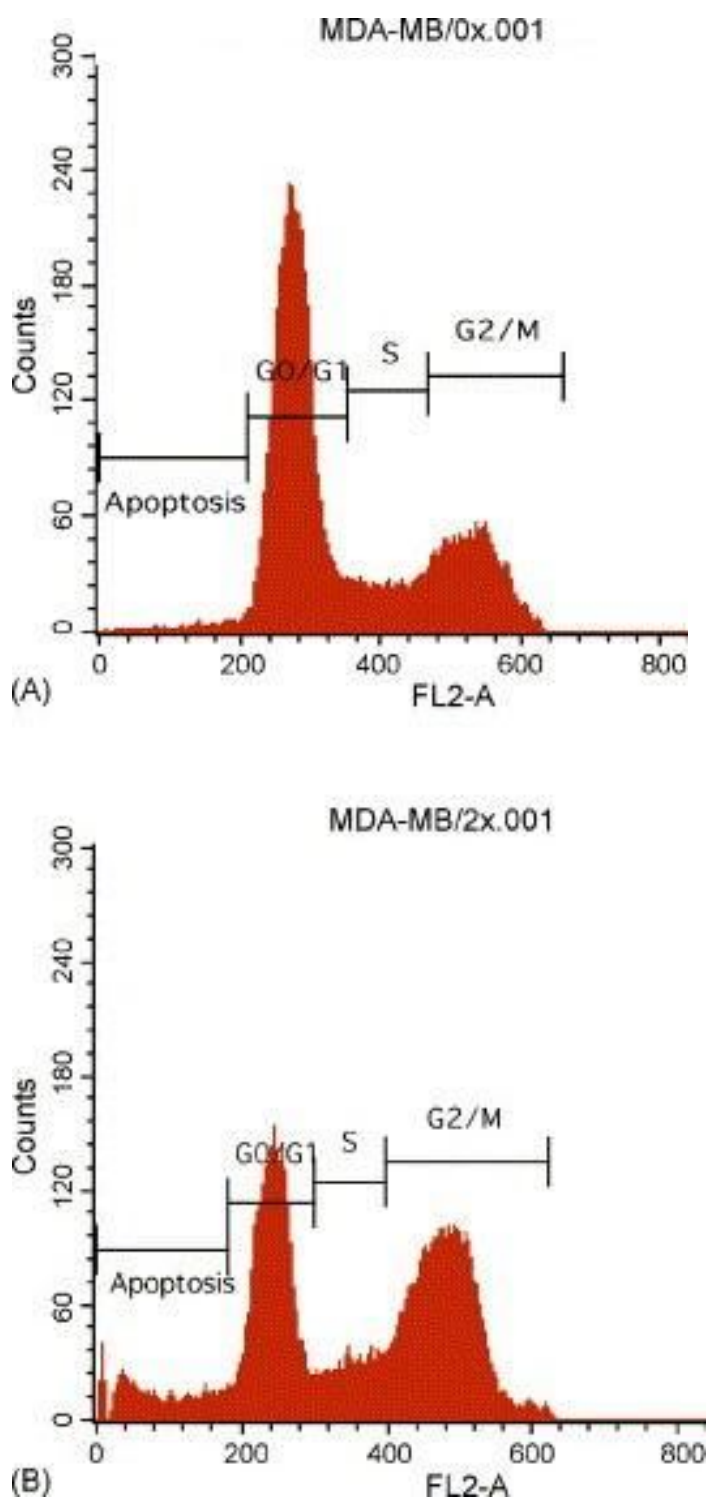

Fig 4: (A) Cell cycle analysis of MDA-MB435 cells without treatment with plant extract. GO/G1 $=65.8$ $\%, S=9.0 \%, G 2 / M=24.4 \%$; (B) Cell cycle analysis of MDA-MB435 cells following treatment with plant extract fraction 3 at $120 \mu \mathrm{g} / \mathrm{ml}$ for $48 \mathrm{~h}$ : $\mathrm{GO} / \mathrm{G} 1=36.8 \%, \mathrm{~S}=10.1 \%, \mathrm{G} 2 / \mathrm{M}=45.7 \%$

SKBR3 cells treated with the fruit extract decreased in number in $S$ phase, whereas MDA-MB435 treated with the extract remarkably accumulated in the $\mathrm{G} 2 / \mathrm{M}$ phase of the cell. This indicates that fraction 3 is capable of suppressing breast cancer cell proliferation, especially MDA-MB435, via cell cycle blockage.

Many anticancer agents derived from plants that are prescribed for treating malignancies inhibit cancer cell growth through cell cycle regulation, including $\mathrm{G} 2 / \mathrm{M}$ accumulation [11]. It is well known that agents that affect the G2/M phase cell cycle arrest act by targeting tubulin or disrupting tubulin-microtubule equilibrium $[12,13]$. Our findings indicate that Limonia acidissima fruit extract exhibited antiproliferative effect on MDA-MB435 breast cancer cells via G2/M cell cycle arrest, and therefore may interact with tubulin in a manner similar to other plant-derived chemotherapeutic agents. However, the antiproliferative activities of this plant may possibly depend on cell type and culture conditions.

\section{CONCLUSION}

Limonia acidissima Linn. fruit fraction 3 inhibits the proliferation of human breast cancer cell lines SKBR3 and MDA-MB435. The cell cycle via G2/M blockage plays some roles in Limonia acidissima Linn.-induced antiproliferative activities in MDA-MB435. However, further chemical and other investigations at molecular level are required to identify the active components that induce growth inhibition and to establish possible correlation between the observed activities of the fruit extract.

\section{ACKNOWLEDGEMENT}

The authors specially thank the Head, University Department of Pharmaceutical Sciences, Utkal University, India for his consistent support for this work. This work was supported by grants from INSPIRE-DST, Ministry of Science \& Technology, New Delhi and University Grants Commission, New Delhi. 


\section{REFERENCES}

1. Globocan 2008 (Fast Stats): Number of cases of breast cancer in India, Cited [2012 May 222]. http://globocan.iarc.fr/factsheet.asp

2. Fargeot $P$, Bonneterre $J$, Roche $H$, Lortholary $A$, Campone M, Praagh IV, Monnier A, Namer M, Schraub M, Barats JC, Disease-free advantage of weekly Epirubicin plus Tamoxifen versus Tamoxifen alone as adjuvant treatment of operable, node-positive, elderly breast cancer patients.. J Clin Oncol 2004; 22: 4622-4630.

3. Cameron $D$, Bell $R$, Optimizing treatment for patients with breast cancer, Oncology. 2004; 31: 4-5.

4. Kirtikar KR, Basu BD. Indian Medicinal Plants. Dehradun, India, International Book Distributors, 2005, Vol I, pp 478-79.

5. Rang HP, Dale MM, Ritter JM, Eds, Pharmacology, Edinburgh: Chuchill Livingstone. 1999.

6. Llango K, Chitra V. Wound Healing and Anti-oxidant Activities of the Fruit Pulp of Limonia Acidissima Linn (Rutaceae) in Rats. Trop $J$ Pharm Res, 2010; 37: 120-125.

7. Senthilkumar KL, Kumawat KB, Rajkumar $M$, Senthilkumar, Antidiarrhoeal activity of bark extracts of Limonia acidissima Linn. Res $J$ Pharm Biol Chem 2010; 1(4): 550-553.
8. Saima Y, Das AK, Sarkar KK, Sen AK, Sur P. An antitumor pectic polysaccharide from

Feronia limonia, Int J Biol Macromol, 2000; 27: 333-335.

9. Rubinstein LV, Shoemaker RH, Paull KD, Simon RM, Tosini S, Skehan P, Scudiero DA, Monks A, Boyd MR. Comparison of in-vitro anticancer-drug-screening data generated with a tetrazolium assay versus a protein assay against a diverse panel of human tumor cell lines J. Natl. Cancer Inst 1990; 82: 111-116.

10. Hardman JG, Limbird JE, Molinoff PB, Ruddon RW, Gillman AG, Eds. Goodman \& Gilman's The Pharmacological Basis of Therapeutics, $9^{\text {th }}$ Ed. New York: Mc Graw-Hill Companies, 1996; pp 461-486.

11. Tanaka Y, Fujiwara K, Tanaka H, Meheta K, Kohno I. Paclitaxel inhibits expression of heat shock protein 27 in ovarian and uterine cancer cells. Int J Gynecol Oncol . 2004; 14: 616-620.

12. Hadfield JA, Ducki S, Hirst N, McGown AT, Tubulin and microtubules as targets for anticancer drugs. Prog Cell Cycle Res 2003; 44: 309-325

13. Schiff PB, Fant J, Horwiz SB. Promotion of microtubule assembly in-vitro by Taxol. Nature 1997; 277: 655-657. 